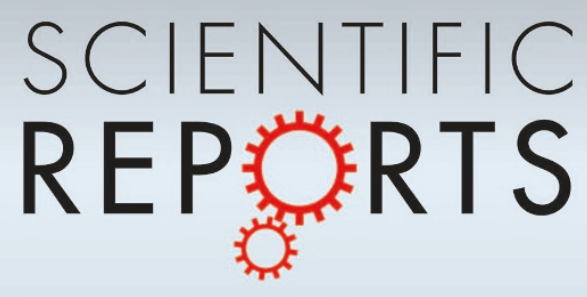

OPEN

SUBJECT AREAS:

HYDROLOGY

ENVIRONMENTAL SCIENCES

HYDROGEOLOGY

CLIMATE-CHANGE IMPACTS

Received

22 April 2013

Accepted

16 December 2013

Published

15 January 2014

Correspondence and requests for materials should be addressed to S.F. (sylvain.ferrant@ cesbio.cnes.fr)

\title{
Projected impacts of climate change on
} farmers' extraction of groundwater from crystalline aquifers in South India

\author{
Sylvain Ferrant ${ }^{1,2,3}$, Yvan Caballero ${ }^{4}$, Jérome Perrin ${ }^{4,6}$, Simon Gascoin ${ }^{1,3}$, Benoit Dewandel $^{4}$, \\ Stéphanie Aulong ${ }^{4}$, Fabrice Dazin ${ }^{5}$, Shakeel Ahmed ${ }^{6} \&$ Jean-Christophe Maréchal ${ }^{4}$
}

\begin{abstract}
'Université de Toulouse, UPS (OMP), GET, 14 av. Edouard Belin, F-31400 Toulouse, France, ${ }^{2}$ IRD, CNRS, GET, F-31400 Toulouse, France, ${ }^{3}$ UPS, IRD, CNRS, CNES, CESBIO, 18 av. Edouard Belin 31400 Toulouse, ${ }^{4}$ BRGM, Water Division, NRE Unit, 1039 rue de Pinville, 34000 Montpellier, France, ${ }^{5}$ SIRS, 27 rue du Carrousel, Parc de la Cimaise, 59650 Villeneuve d'Ascq, France,

IIndo-French Centre for Groundwater Research, N.G.R.I., Uppal Road, Hyderabad 500 606, India.
\end{abstract}

Local groundwater levels in South India are falling alarmingly. In the semi-arid crystalline Deccan plateau area, agricultural production relies on groundwater resources. Downscaled Global Climate Model (GCM) data are used to force a spatially distributed agro-hydrological model in order to evaluate Climate Change (CC) effects on local groundwater extraction (GWE). The slight increase of precipitation may alleviate current groundwater depletion on average, despite the increased evaporation due to warming. Nevertheless, projected climatic extremes create worse GWE shortages than for present climate. Local conditions may lead to opposing impacts on GWE, from increases to decreases $(+/-20 \mathrm{~mm} /$ year), for a given spatially homogeneous CC forcing. Areas vulnerable to CC in terms of irrigation apportionment are thus identified. Our results emphasize the importance of accounting for local characteristics (water harvesting systems and maximal aquifer capacity versus GWE) in developing measures to cope with CC impacts in the South Indian region.

T he Fourth Assessment Report of the Intergovernmental Panel on Climate Change ${ }^{1}$ stated that increasing atmospheric concentrations of trace greenhouse gases will lead to global disturbances in the Earth's hydrological and biological systems. In the meantime, the demand for fresh water is increasing in many parts of the world. This trend is challenging the future water management and raising the need to document both human and climate change influences on water resources. Several studies have recently assessed the regional impacts of climate change (CC) on hydrology, focusing on surface water ${ }^{2-4}$, reservoir management ${ }^{5}$, or recharge to aquifers (see Taylor et al. ${ }^{6}$ for a review). Regarding groundwater, aquifers are not only subjected to variations in natural recharge but are also deeply impacted by worldwide groundwater extraction (GWE) to supply the needs of two billion people. In 2000, irrigation accounted for $70 \%$ of global freshwater withdrawals from rivers, lakes, and groundwater. Two major opposing effects of irrigation on aquifer dynamics are identified: groundwater depletion in regions with primarily groundwater-fed irrigation, and groundwater accumulation in regions dominated by return flows from irrigation fed by surface-water ${ }^{7-14}$. In irrigated areas, both CC and GWE have to be integrated in order to properly study the evolution of groundwater resource.

Döll et al. ${ }^{15}$ computed sector-specific groundwater and surface water withdrawals at the global scale, with a spatial resolution of $0.5^{\circ}$. They estimated that the impact of water withdrawals on continental storage is significant in arid and semi-arid regions with intensive irrigation. A world-wide assessment of irrigation related to groundwater depletion estimated the Gross Crop Water Demand in India to be around $600 \mathrm{~km}^{3} /$ year $(24 \%$ of the world wide demand of major groundwater users); $59 \%$ of this represents irrigation, $11 \%$ of which is non-renewable ${ }^{16}$. Two thirds of southern India overlies crystalline basement areas where unconfined aquifers are used for intensive irrigation under semi-arid climates. Drought-prone areas (areas of climatic droughts caused by a drop in rainfall below about $75 \%$ of normal values for $20 \%$ of the year), are limited to $6.4 \%$ in Andhra Pradesh State (against $11.3 \%$ in Karnataka and $38 \%$ in Rajasthan ${ }^{17}$ ). Consequently, the water management concern in Andhra Pradesh is the falling groundwater table (groundwater scarcity or aquifer drought), which is related to climate variability and GWE intensity. Tiwari et al. ${ }^{18}$ used GRACE and well-water levels from the Central Groundwater Board (CGWB, Andhra Pradesh, India) to identify spatial and temporal groundwater storage variations in Andhra Pradesh between 2002 and 2008. By comparing the continental water estimates with GRACE satellite with the 
groundwater storage, they notably found a high rate of recharge associated with the exceptionally humid monsoon in 2005: around $300 \mathrm{~mm}$ of water were accumulated between June and October.

Numerous studies have been published during the last decade describing the dominant hydrogeological processes that affect the groundwater budget in this specific semi-arid irrigated context ${ }^{19-24}$. Perrin et al. ${ }^{25}$ calibrated an agro-hydrological model (Soil and Water Assessment Tool, SWAT $\left.{ }^{26}\right)$ in a small watershed $\left(84 \mathrm{~km}^{2}\right.$, Andhra Pradesh) on seasonal aquifer recharge using agricultural land-use map derived from remote sensing and the associated GWEs for irrigation, groundwater-capacity maps derived from field observations and percolation-tank locations and capacity. They demonstrated that the runoff stored in the network of percolation tanks (called Water Harvesting System, WHS) accounts for half of the aquifer recharge and that groundwater depletion locally limits the GWE associated with the local irrigation demand. This modeling approach explored the spatial variability of groundwater scarcity and the resulting irrigation-water shortages under current conditions of climate variability. Mechanisms behind these shortages suppression are associated with a non-renewable GWE which leads to an overall groundwater depletion from year to year ${ }^{16}$. For the South Indian context, Wada et al. ${ }^{16}$ computed an estimated annual deficit of groundwater (lower recharge than extraction) for the year 2000. This overall picture compiled for a single year needs to be supplemented for this context of low storage shallow aquifers by the results presented in Perrin et al. ${ }^{25}$ : temporary scarcity could be balanced by high recharge rates in few years.

The Kudaliar catchment $\left(983 \mathrm{~km}^{2}\right)$ is located in Andhra Pradesh State, $50 \mathrm{~km}$ north of Hyderabad (Figure 1). It is representative of the northern part of the Deccan plateau region regarding the irrigated agriculture, climate and hydro-geological settings. It is characterized by a flat topography (from 430 to 640 meters above sea level) and an absence of perennial streams. The geology of the watershed is relatively homogeneous and is mainly composed of the Archean granites commonly found on the Deccan plateau. The region has a semi-arid climate controlled by the periodicity of the Southwest monsoon: a rainy "Kharif" (local name) season from June to September and a dry "Rabi" (local name) season from November to March. The hottest season (April and May) is called summer. Annual precipitation (1980-2000) ranges from $540 \mathrm{~mm}$ to $1300 \mathrm{~mm}$ with a mean of $879 \mathrm{~mm}$ (Indian Meteorological Department - $\mathrm{IMD}^{27}$ ), of which $88 \%$ falls during the monsoon. The annual mean temperature is $26^{\circ} \mathrm{C}$, although in summer the maximum temperature may reach $45^{\circ} \mathrm{C}$.

The catchment is mainly rural, densely populated $(300,000$ inhabitants in $983 \mathrm{~km}^{2}$ ), a small town (Gajwel, 30,000 inhabitants) located in the southwestern part. About $60 \%$ of the catchment is covered by semi-arid natural vegetation (bush). Rain-fed crops (maize and cotton) are sown only during the monsoon period. Irrigated areas cover around $2 \%$ of the watershed area in dry season and around $8 \%$ during monsoon; these extents are subjected to be adapted to aquifer and/or climatic drought. Daily rice and vegetable irrigation rates were estimated from field surveys (measurements of instant well discharges, irrigated field areas, and monitoring of daily pumping durations). Daily irrigation rates for rice are $12 \mathrm{~mm} /$ day and $9 \mathrm{~mm} /$ day for Rabi and Kharif respectively ${ }^{28}$. A land-use map (Figure 1) is employed to represent the spatial distribution of irrigation water demand (IWD) derived from farmers practices and crop

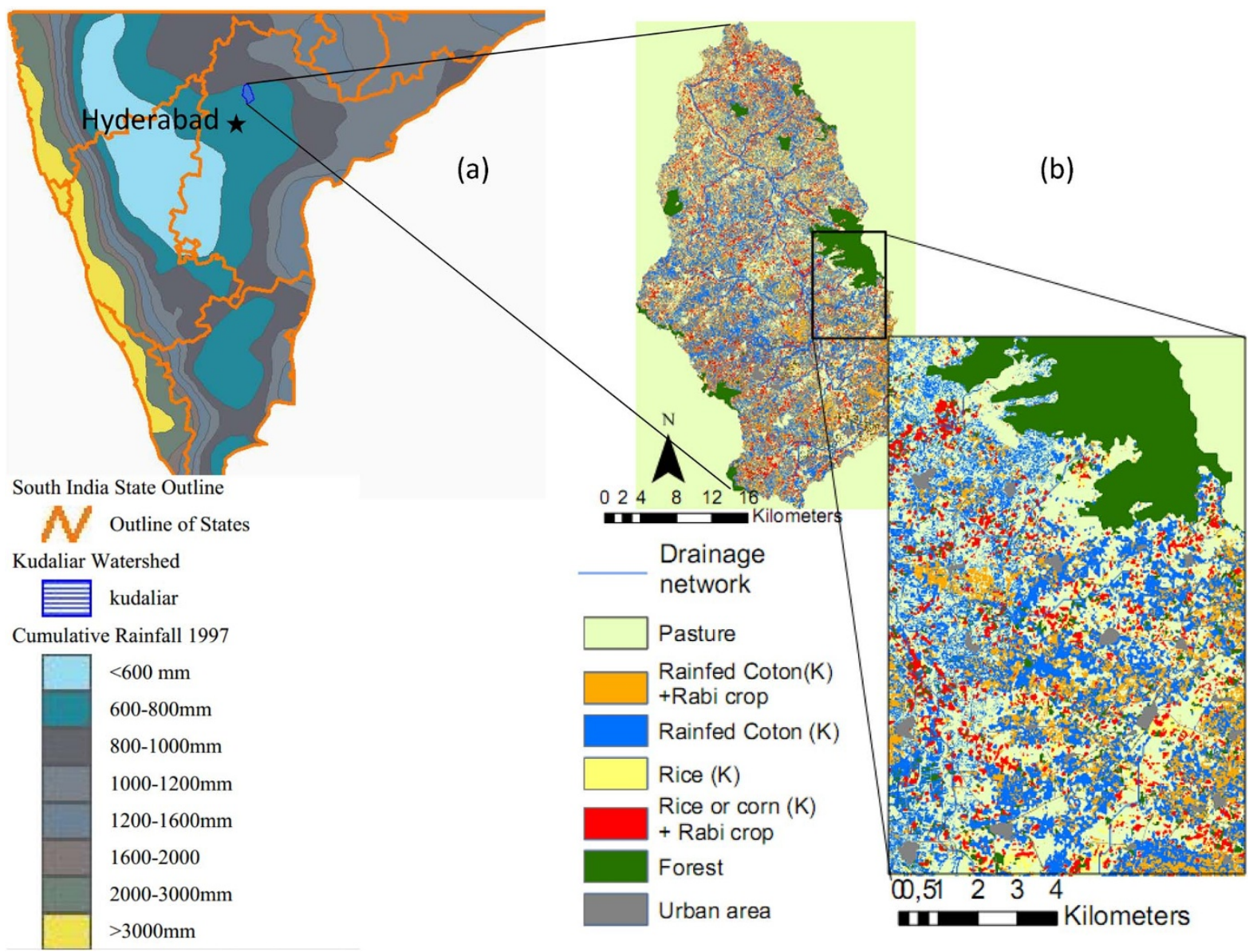

Figure $1 \mid$ The Kudaliar catchment in Andhra Pradesh, South India: the semi-arid climatic setting of the Deccan Plateau (a), land-use map obtained by remote sensing in 2009-2010 (b) (SIRS contribution) with an enlargement of the land-use map to illustrate the high spatial resolution obtained. Made with ESRI 2009. ArcMap Version 9.3.1. 
location within the watershed. The observed IWD is systematically higher than the plant water demand, a part of irrigated water is percolating back to the aquifer as return flow. Although the extent of the irrigated area is limited, the corresponding IWD is close to the average natural recharge $e^{25}$ that is itself highly variable from year to year $^{25}$ (for instance $60 \mathrm{~mm}$ and $25 \mathrm{~mm}$ respectively for 2009 and 2010 , figure $2 \mathrm{a}$ ). The study is focusing on climate change impact only; to do so, the land-use map and spatial IWD distribution are fixed for both historical and future periods.

The crystalline aquifer is the main source of water for irrigation, since the rivers are not perennial. Groundwater is stored in the weathering profile on the crystalline basement, where two layers with contrasting hydrodynamic properties are defined: the saprolite layer, with the lowest hydraulic conductivity and highest porosity (1-5\%) and the underlying fissured layer with the highest hydraulic conductivity and lowest porosity $(0.5-1 \%)^{20,23}$.

Several published climate-change impact assessments predict future water shortages, especially when large volumes of water are extracted for irrigation ${ }^{29}$. CC should impact recharge rates and mechanisms ${ }^{29}$ depending upon the combination of soil and vegetation types ${ }^{14}$. Based on the field observations and modeling approach, the present study explores the hydrological impacts of CCs and the consequences for GWE under current agricultural practice in the
Kudaliar catchment. We used the SWAT modeling tool calibrated in Gajwel watershed $\left(84 \mathrm{~km}^{2}\right.$ presented in Perrin et al. $\left.{ }^{25}\right)$ and applied to a dataset at the Kudaliar watershed scale $\left(983 \mathrm{~km}^{2}\right)$; we compared the hydrological outputs for a past and a projected situation using a set of four GCMs output selected for their representativeness of the monsoon $^{35}$ (GCMs - CGCM3 ${ }^{30}$; CNRM-CM3 ${ }^{31}$; ECHAM5 ${ }^{32}$; BC$\mathrm{CR} 2^{33}$ ) under the most probable greenhouse-gas emission scenarios (IPCC SRES A2 ${ }^{34}$ ). These outputs have been downscaled ${ }^{36}$ using the Indian Meteorological Department data $^{27}$ (see method section for details).

\section{Results}

Projected climate change. The four selected climate models predict an increase in seasonal precipitation and in precipitation variability, and a possible extension of the monsoon period ${ }^{35,36}$. In the Kudaliar area, maximum seasonal rainfall changes are projected during the monsoon season. These are most pronounced during May-June and August, when rainfall would tend to increase (from 15\% to $50 \%$ depending on the scenario). Moderate negative changes are projected during dry season, which does not impact much the annual rainfall. Maximum surface temperature changes are projected during the dry season, particularly in February-March $\left(+2.5^{\circ} \mathrm{C}\right)$. During the

a)

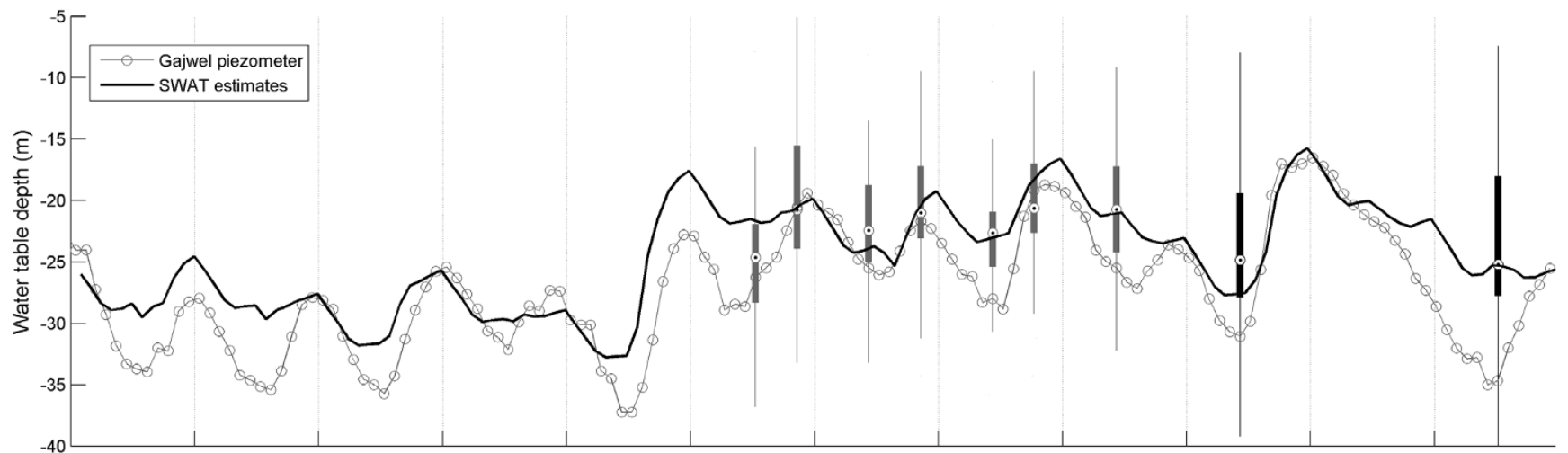

b)

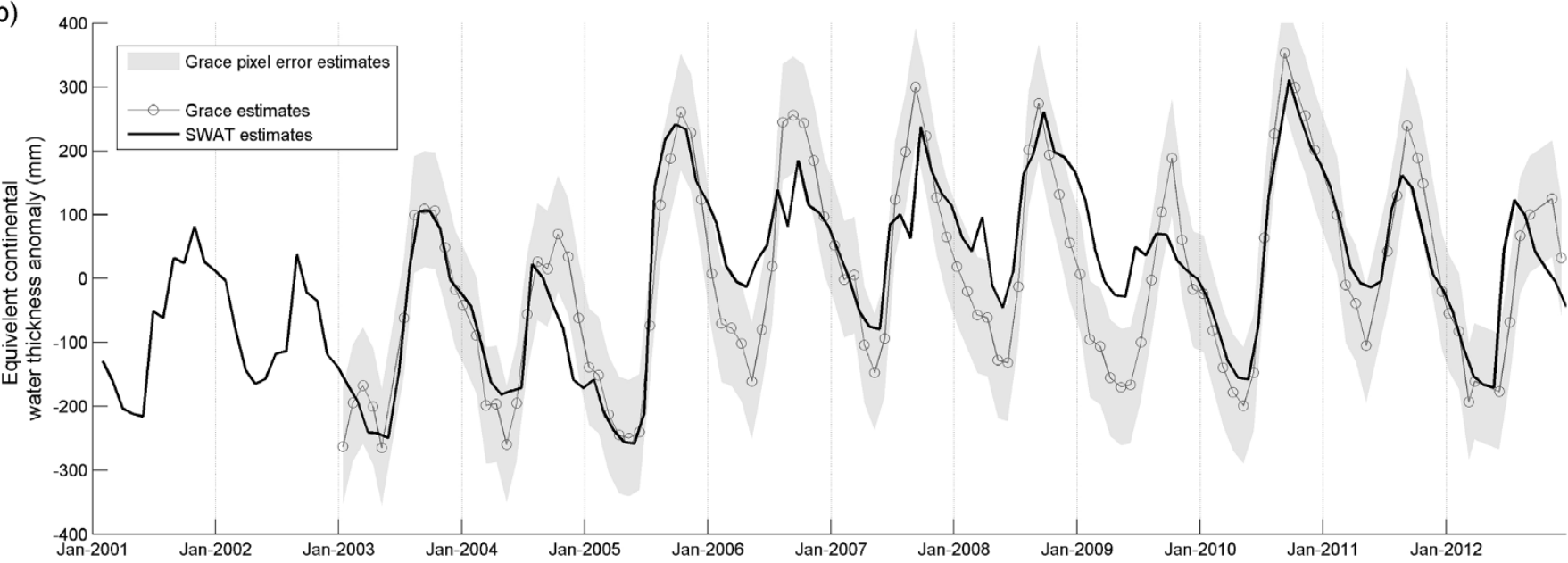

Figure $2 \mid$ (a) comparison between monthly groundwater table depth simulated with SWAT-IMD (Black line) at the Kudaliar watershed scale and observed at the Gajwel piezometer location, in Gajwel town (Grey line). The average specific yield of 0.016 found for the Kudaliar watershed ${ }^{24}$ associated with the local depth of fresh basement (37 $\mathrm{m}$ depth) is used to convert the simulated groundwater storage in mm into a water table depth. Grey and black boxplots represent the spatial distribution of groundwater table depth measured during piezometric surveys respectively in 40 to 60 boreholes throughout the Gajwel watershed $\left(84 \mathrm{~km}^{2}\right)$ and in 200 boreholes throughout the Kudaliar watershed $\left(983 \mathrm{~km}^{2}\right)$. The circle with a dot stands for the median value of each dataset. (b) Comparison between monthly continental water storage (CWS) anomaly (surface/soil/groundwater divided by the average for the study period) simulated for the Kudaliar catchment $\left(983 \mathrm{~km}^{2}\right)$ using SWAT-IMD (black line) and monthly GRACE liquid water equivalent thickness anomaly (grey line) for the region where the study site is located $\left(90,000 \mathrm{~km}^{2}\right)$. The confidence interval of GRACE estimates given for this location is represented by the grey area $\left(1^{\circ}\right.$ resolution, downloaded from http://grace.jpl.nasa.gov/data/gracemonthlymassgridsland/). 
monsoon season, smaller variations are projected, with a minimum in August $\left(+1.5^{\circ} \mathrm{C}\right)^{36}$.

In the following, SWAT-BCCR, SWAT-CGCM, SWAT-CNRM, and SWAT-ECHAM will be used to refer to the hydrological results of a SWAT simulation using the corresponding GCM climate scenario (1980-2000 and 2045-2065). Based on the hypothesis that each projected climate scenario is equally likely, the results of the four SWAT simulations were averaged and will be referred to here as the multi-model SWAT-GCM scenario. Finally, SWAT-IMD refers to the forced hydrological simulation using observed IMD (Indian Meteorological Department) climate data for the historical period (1980-2012). The IMD data set comprises actual temperature and precipitation monitored by ground stations between 1971 and 2012 and covering the whole of India with a 0.5 degree grid resolution ${ }^{27}$.

SWAT continental water estimates (SWAT-IMD) versus observations. SWAT calibration has been performed at a sub-basin scale (Gajwel watershed, $84 \mathrm{~km}^{2}$ ) embedded in the Kudaliar catchment $^{25}$. Three types of observations that span different time and space scales are used to demonstrate the of the water storage representation by the model. First, the groundwater level depth recorded in a borehole located in the Gajwel town (small dots, figure 2a) shows the local fluctuations of the water table, which sometime cannot be considered as representative of the basin average. It however gives the relative long term variation trends. A second set of depths to the water table ranges (vertical bars, figure 2a) corresponds to local measurements observed on 40 to 60 piezometers (usually abandoned wells) during the driest and wettest conditions, between 2006 to 2009 (presented in Perrin et al. ${ }^{25}$ ) at the Gajwel watershed scale. Two additional sets of water levels monitored in June 2010 and 2012 at the Kudaliar catchment scale $\left(983 \mathrm{~km}^{2}\right)$ give an overview of the spatial variability at the study site scale. The comparison of these three sets of data shows that the water level depth is highly variable with space and time, and that the SWAT GW estimates are realistic over time.

In addition to that, regional estimates of terrestrial water thickness derived from GRACE satellite observations have been used to evaluate the representativeness of SWAT water cycle and water uses at the regional scale. Figure $2 \mathrm{~b}$ presents the variation of the monthly Continental Water (CW, surface, soil and groundwater) expressed in term of an anomaly measured from Grace Satellite (year 2002 to 2012). We used the GRACE monthly mass grid, associated error and scaling factors from the Center for Space Research data center optimized for land applications (Release $05^{39,40}$ ). This anomaly is representative of an area of $90,000 \mathrm{~km}^{2}$ which includes the $983 \mathrm{~km}^{2}$ of the Kudaliar study site. SWAT estimates of soil, groundwater and surface reservoir storages are plotted as an anomaly to the monthly mean simulated between 2001 and 2012. Irregular peaks are simulated in 2006 and 2007, corresponding to local maximum of CW associated to localized high rainfall event at the edge of the monsoon period. Apart from that heterogeneities that does not match with regional
GRACE estimates, the comparison suggests that CW estimates at the catchment scale follows the regional trends estimated from GRACE measurements. It clearly demonstrates that there is no long term bias in the estimations of continental water storage, meaning that effective precipitations simulated with SWAT, balanced by realistic GWE does not lead to bias in the continental water estimates, i.e. there is neither accumulation of water in the aquifer nor long term drop of water table. The calibrated model is therefore considered well suited for the evaluation of projected climate impacts under current IWD.

Water-balance development at basin scale. The simulated components of the water balance for the historical and future 20-year periods are shown for each climate scenario in Table 1. Considering the average values among all GCMs (last column of Table 1), it can be seen that the projected rainfall increase of $81 \mathrm{~mm} \cdot \mathrm{y}^{-1}$ is divided into recharge $\left(20 \mathrm{~mm} \cdot \mathrm{y}^{-1}\right)$, evapotranspiration from the soil/plant system $\left(26 \mathrm{~mm} \cdot \mathrm{y}^{-1}\right)$, and discharge $\left(44 \mathrm{~mm} \cdot \mathrm{y}^{-1}\right)$; $9 \mathrm{~mm} \cdot \mathrm{y}^{-1}$ of the recharge surplus discharges from the aquifer into the stream and is part of the $44 \mathrm{~mm} \cdot \mathrm{y}^{-1}$ simulated discharge. The large increase in projected discharge at the outlet of the catchment is linked to the increase in simulated runoff and in aquifer contributions to stream water. For the historical projections, an average of $178 \mathrm{~mm} \cdot \mathrm{y}^{-1}$ of stream water flows into the WHS. The depletion of these small reservoirs during the historical period (SWAT GCM) is estimated as follows: $49 \mathrm{~mm} \cdot \mathrm{y}^{-1}$ seepage into the aquifer, $36 \mathrm{~mm} \cdot \mathrm{y}^{-1}$ evaporation from the surface water, $92 \mathrm{~mm} \cdot \mathrm{y}^{-1}$ discharge at the catchment outlet. These discharge episodes occur only for short periods during humid years, when runoff from the highest rainfall events fills the WHS and overflows reach the stream at the catchment outlet. The perturbation of seepage and evaporation from the WHS increases by only 3 to $4 \mathrm{~mm}$ (not shown in the table). The increase in stream discharge mainly occurs during the monsoon period in more humid years when the WHS is full. The discharge at the outlet from the catchment (the volume of water discharging from the WHS) is thus the most disturbed, with an increase of $44 \mathrm{~mm} \cdot \mathrm{y}^{-1}$.

Future evolution of groundwater storage. The simulated seasonal groundwater storage (GWS) for the historical and future periods averaged over the whole Kudaliar catchment area are compared in Figure 3 for each climate scenario and for the multi-model scenario. The average monthly GWS values are computed each year for a selection of dry months (March, April and May) and wet months (August, September, October). The distributions of these seasonal GWS values are compared for the past and the future periods for each GCM.

The high amplitude of GWS distributions for all scenarios and for both periods lead to non statistically significant changes between past and future GWS regarding variance (Fisher in the case of normality) or mean (Student's t-test or Wilcoxon Mann-Whitney, for parametric and non-parametric distributions respectively). The only

Table 1 | Major annual water flows (in $\mathrm{mm}$ ) simulated by SWAT using simulated climate data for the historical (1980-2000) and projected (2045-2065) periods with GCM models (BCCR, CGCM, CNRM and ECHAM) for the Kudaliar watershed. PRECIP, CAP-R, AQRCH, AET, WEXTR, and DISCH respectively indicate Precipitation, Capillarity rise from the groundwater table, Aquifer Recharge, Actual EvapoTranspiration, simulated GroundWater Extraction, Irrigated Water Demand and Discharge at the Kudaliar catchment outlet

\begin{tabular}{lccccccccc} 
W flux mm/y & $1980-2000$ BCCR & CGCM & CNRM & ECHAM & 2045-2065 BCCR & CGCM & CNRM & ECHAM & $\begin{array}{c}\text { SWAT-GCMs } \\
\text { diff(mm) }\end{array}$ \\
\hline PRECIP & 965 & 976 & 985 & 930 & 999 & 1164 & 1063 & 956 & +81 \\
CAP-R & 7 & 10 & 7 & 6 & 9 & 19 & 10 & 8 & +4 \\
AQRCH & 237 & 248 & 247 & 228 & 252 & 300 & 257 & 234 & +20 \\
AET & 810 & 782 & 809 & 787 & 822 & 842 & 836 & 796 & +26 \\
GWE* & 208 & 206 & 210 & 204 & 211 & 203 & 210 & 207 & +0 \\
IWD & 214 & 214 & 214 & 214 & 214 & 214 & 214 & 214 & X \\
DISCH & 78 & 123 & 96 & 71 & 93 & 219 & 149 & 83 & +43 \\
\hline
\end{tabular}


significant change is found for wet periods for the SWAT-CGCM model (Kolmogorov-Smirnov test with $\mathrm{p}$ value $<0.05, \mathrm{n}=40$ ), with a high increase of the average and maximal GWS values. Indeed, among the four GCMs used in this study, only CGCM exhibited a significant statistical change in variance and mean between future and past climates.

The seasonal GWS values for the multi-model SWAT-GCM scenario (SWAT-GCMs box-plot in Figure 3) show significant differences in variance (Fisher test) for the wet season ( $p$ value $<0.05$ ), whereas the mean values are statistically similar. An overall increase by $50 \mathrm{~mm}$ in the future GWS is projected for both seasons.

Even if changes are not statistically significant, hydrological extremes are projected to intensify. Difference between the first and third quartile increases sharply for SWAT-CGCM and SWATCNRM, whereas a moderate changes are estimated for SWATECHAM and SWAT-BCCR for respectively both dry and wet season. Moreover, average GWS is predicted to drop for SWAT-ECHAM. In this last case, the increase in the recharge related to the increase in precipitation is balanced by an increase of GWE and the evapotranspiration ( 3 and $2 \mathrm{~mm}$ respectively in table 1 ).

Frequency of aquifer drought. The drop of GWS directly limits the GWE. We arbitrarily have fixed a GWS threshold $(50 \mathrm{~mm})$ below which we consider the aquifer to be in a stress situation (aquifer drought), in order to evaluate the length of groundwater scarcity period that occurred after successive climatic drought. For each sub-basin and each past and future climate, the duration of aquifer drought periods is computed. More than averages GWS, this variable gives a good insight of the impact the climatic variable dynamics on average drought period duration during which farmers experience water scarcities, i.e. GWE does not meet the IWD.

Figure 4 shows the distribution of differences in the duration of drought periods between future and past. This difference is expressed for each sub-basin in months per year of increase or decrease based on the 20 years of simulation period. The hydrological response varies according to the climate scenario being considered: an overall decrease in drought conditions is projected for SWAT-BCCR (up to 2 months per year), an overall increase in drought periods of up to 2 months is projected for SWAT-CGCM, and a stable situation is projected for the SWAT-CNRM scenario, which also gives the smallest changes between present and future (in terms of the number of days of increase/decrease). A contrasting hydrological response is projected for SWAT-ECHAM: the duration of drought periods decreases in two thirds of the catchment and increases elsewhere.

Taking each scenario as equally likely, the average projected response to droughts (SWAT-GCM) shows both moderate increase and decrease of drought period duration for respectively 19 and 9 subbasins.

Future evolution of discharge. Discharge events occur during the southwestern summer monsoon period (usually from June to September but this is highly variable from year to year, and rainfall may occur until November). Figure 5 (left) shows the impact of averaged climate scenarios (SWAT-GCM) on mean monthly discharge for the historical and future periods. An uncertainty envelope related to the variability between the four climate scenarios was constructed by using the standard deviation around the mean monthly simulated discharges for both periods. Although the first monsoon rainfall usually occurs in June, no discharge is simulated for the present climate. This is consistent with observations, since the rainfall is stored in the soil, aquifer, and tanks.

For the future period, an average value of $15 \mathrm{~mm}$ for river discharge is simulated in June. Discharge is projected to increase in the future from its present values during July and August. Future monsoon discharge and extreme events are likely to begin one month earlier (in June). Variability in the mean future/past discharge ratio among climate scenarios is higher for the beginning of the monsoon season than for the end (Figure 5, right panel). While the general picture is an increase in discharge, some scenarios (ECHAM in June and BCCR in September) project a moderate decrease in discharge.
SWAT-BCCR

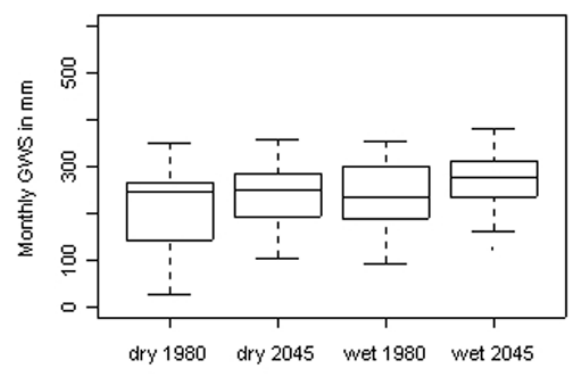

SWAT-ECHAM

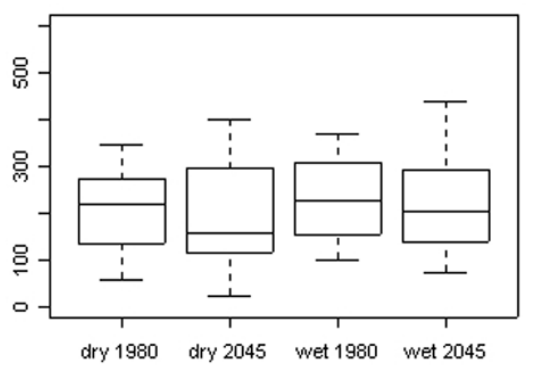

SWAT-CGCM

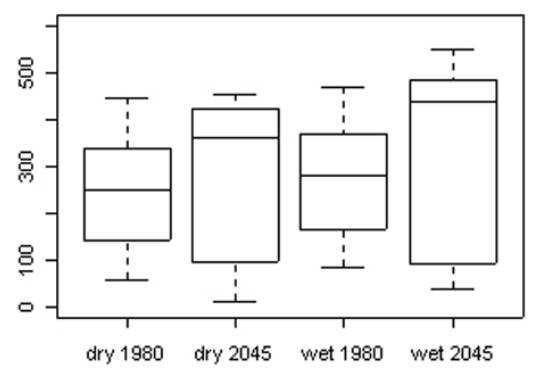

SWAT-GCMs

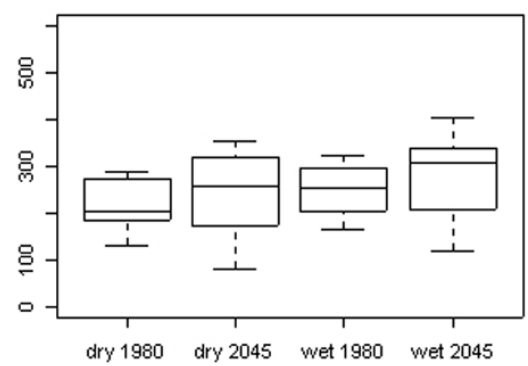

SWAT-CNRM

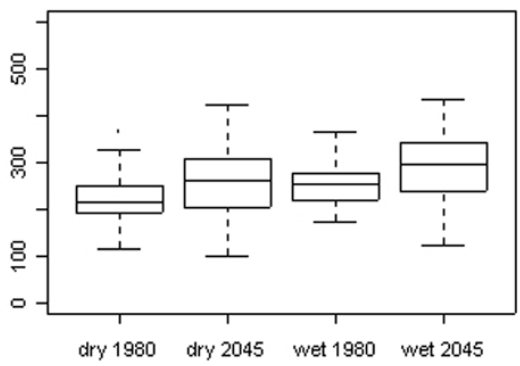

Figure 3 Average monthly dry and wet season Ground Water Storage (GWS) in mm for each SWAT-GCM for the historical (1980-2000) and projected (2045-2065) periods. The average GWS simulated for the four GCM outputs is shown (SWAT-GCM). The minimum, maximum, first and third quartile, and median of seasonal GWS are shown in each box-plot. The asterisk stands for the significance of the Kolmogorov-Smirnov test with p value $<0.05$ for SWAT CGCM and for the Fisher test for SWAT GCMs. The black circles represent outliers. 


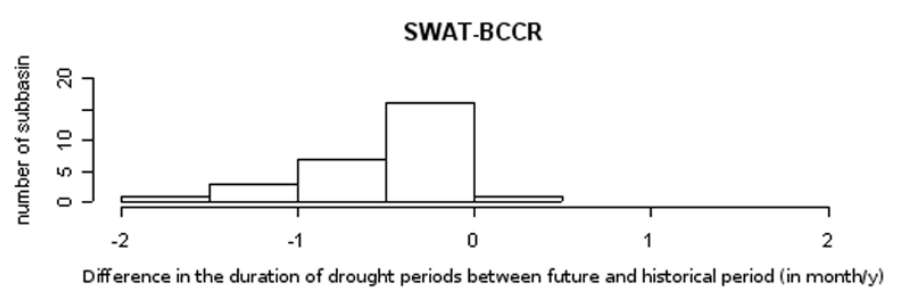

SWAT-CNRM

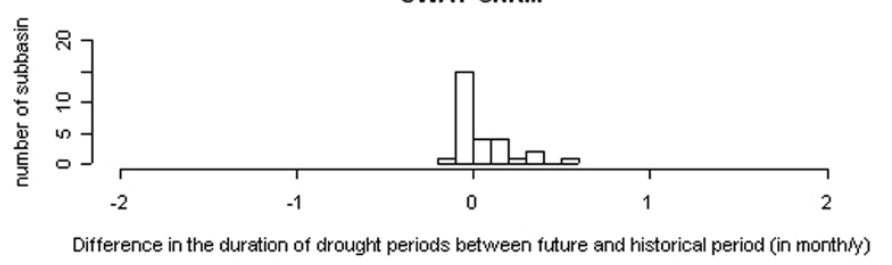

SWAT-GCMs

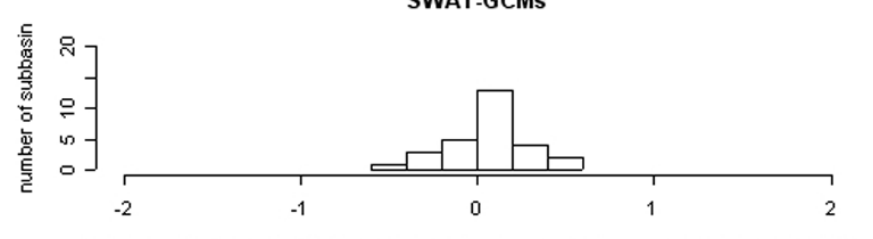

Difference in the duration of drought periods between future and historical period (in month/y)

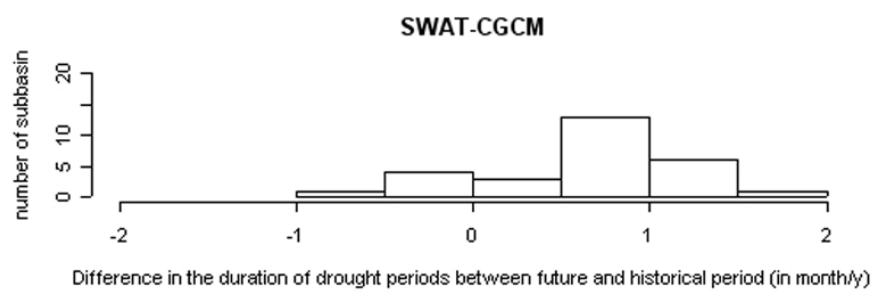

SWAT-ECHAM

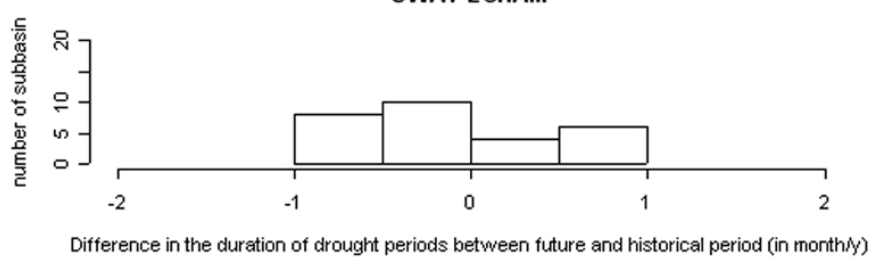

Figure 4 | Aquifer drought-period duration differences for each sub-basin between the historical and future periods, in months per year. Histograms represent the number of sub-basins for each class of differences in duration. The first four histograms correspond to each climate scenario. The last (SWAT-GCMs) corresponds to the future/historical differences averaged for the four climate scenarios for each sub-basin. For a better representation, classes of differences in duration are adapted to each distribution: this explains why the column widths vary.

Every scenarios indicates an increase in discharge in November and December, with a ratio ranging from 1.1 to 1.6 .

Simulated groundwater extraction. The local groundwater extraction (GWE) simulated with SWAT is equal to irrigation water demand (IWD, obtained from land-use and field estimates) when groundwater is available. If the aquifer is depleted, the groundwater extraction computed by the model becomes lower. Mean seasonal GWEs for all climate projections are shown in Figure 6. The groundwater demand is met overall during both periods, since the median, quartile, and maximum values overlap with the IWD.

The outliers located below each box-plot correspond to seasons with a GWE lower than the IWD. They stand for seasons during which the groundwater shortages affect the extraction. These shortages are simulated during one to four seasons over 20 years of simulation, during which the sub-basin aquifers is empty. The missing amount of GWE varies among years and GCMs, from an almost total restriction of the GWE (GWE around $20 \mathrm{~mm}$ for one wet season in 2045-2065 for SWAT-CGCM) to moderate restrictions (more than half of the IWD is fulfilled under SWAT-CNRM and SWAT-BCCR). A limitation by $20 \mathrm{~mm}$ of the GWE as reported the figure 6 corresponds to a limitation that occurred during a crop growth period of about $300 \mathrm{~mm}$ in the irrigated area, given the irrigated area's extent (around $10 \%$ of the whole catchment area). This lack of irrigated water is assumed to barely affect the seasonal crop yields.

Impacts of CC on GWE are reported in Table 1 in $\mathrm{mm} \cdot \mathrm{y}^{-1}$. Opposite impacts are estimated: 2.9 and $2.7 \mathrm{~mm} \cdot \mathrm{y}^{-1}$ for SWATBCCR and SWAT-ECHAM respectively to -3 and $-0.4 \mathrm{~mm} \cdot \mathrm{y}^{-1}$ for SWAT-CGCM and SWAT-CNRM respectively. These changes are negligible in term of hydrological cycle but not negligible regarding agricultural productivity: an increase by $2.9 \mathrm{~mm} \cdot \mathrm{y}^{-1}$ of GWE simulated with SWAT-BCCR at the sub-basin scale corresponds to an increase of $1000 \mathrm{~mm}$ of irrigated water applied on irrigated area for the three years experiencing limitations. This additional amount of water is of importance for the seasonal crop productivity.
Figure 7 shows a map of the future evolution of the GWE for each sub-basin. The ratio is computed using the average annual water extraction projected for the future and past period under the SWAT-GCM multi-model scenario. The spatial heterogeneity of the GWS trends depends mainly on the local capacity of the WHS, the IWD, the total groundwater capacity, and the previous local GWE limitation.

Since the groundwater demand is met during most seasons and years, apart from a few hydrological dry periods, fluctuations in the ratios between sub-basins are low, ranging from a decrease of $1.3 \%$ to an increase of $3.1 \%$ of mean annual GWE. These percentages are averaged per year at the catchment scale and correspond to a deficit or surplus of irrigated water that occurs during one to four growing seasons over the 20 -year simulation period. For instance, a deficit of 10-20 mm of extraction for one growing season corresponds to 160$330 \mathrm{~mm}$ for the irrigated areas (using 6\% of irrigated area in the catchment), i.e., 18 days to 1 month of irrigated water scarcity during the monsoon and 14 to 27 days during the Rabi season. These temporary shortages affect locally the crop productivity.

Future climatic extremes will then have opposing local impacts on GWE. The WHS in the southeast part of the basin is marked by a high density of small reservoirs and intermediate IWD (limited areas of rice cultivated twice a year). This combination leads to an increase in overall GWS for the future period under nowadays IWD. Conversely, highest IWD are located in the western part of the catchment where lowest aquifer capacity is found: aquifer experiences drier conditions under the future climate scenario. As a consequence, aquifer droughts cause more severe periodic restrictions on irrigation volume than under past conditions. Some areas also experience very small changes because the GWE is not restricted under present or future climates.

\section{Discussion}

SWAT model has been used to integrate a wide range of input data that amount to substantial monitoring effort: high resolution land 

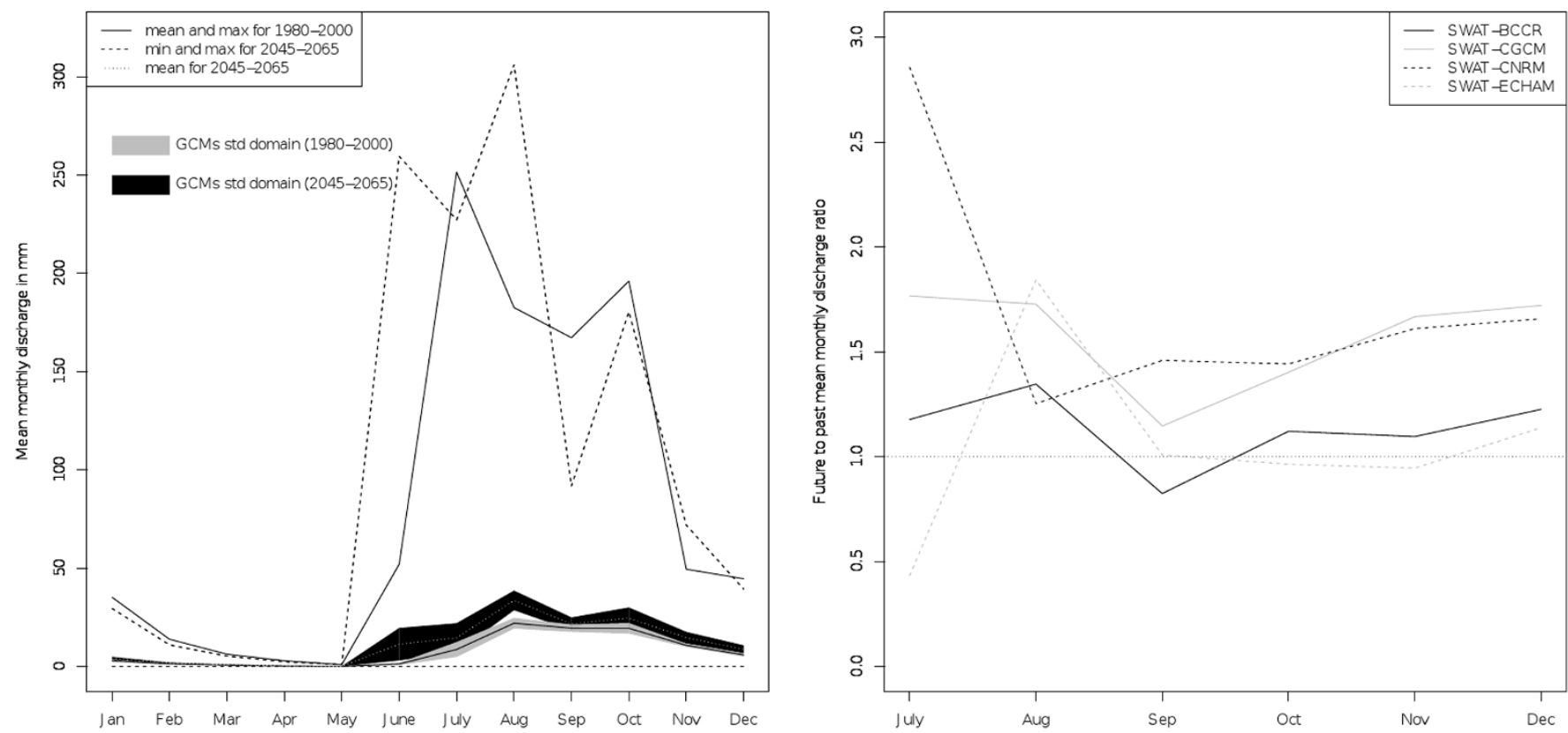

Figure $5 \mid$ Monthly discharge simulated for the historical period and the forecast period for SWAT-GCM. The standard deviation around the mean monthly discharge values is used to delimit a variability envelope (left). The projected future/historical monthly discharge ratio, averaged for each SWAT simulation, is shown from July to December, the months during which discharge occurs (right).

use imagery, aquifer parameter mapping, IWD mapping based on agricultural practices surveys. The aim is to link human and climatic impacts on the groundwater and its agricultural uses in the hard-rock Indian context. Since SWAT has been calibrated on total recharge and recharge under irrigated area, a perfectible calibration is needed to get a better spatial representation of the recharge under non irrigated area (both rain-fed to non agricultural area). This could be achieved by estimating the seasonal evapotranspiration of natural land cover spatially, using remote sensing data for contrasted years ${ }^{41}$.
The uncertainty surrounding climate-model outputs is explored using four climate models. Although climate models are able to produce relatively accurate simulations of Indian summer monsoon rainfall ${ }^{35,42}$, they represent one of the main sources of uncertainty for the impact of climate change on groundwater studies ${ }^{29}$. Moreover, daily simulated precipitation is by far the least accurate estimation provided by these models ${ }^{43}$. We did not explore other sources of uncertainties than the one linked to climate modeling, like those related to the downscaling techniques, hydrological modeling, and
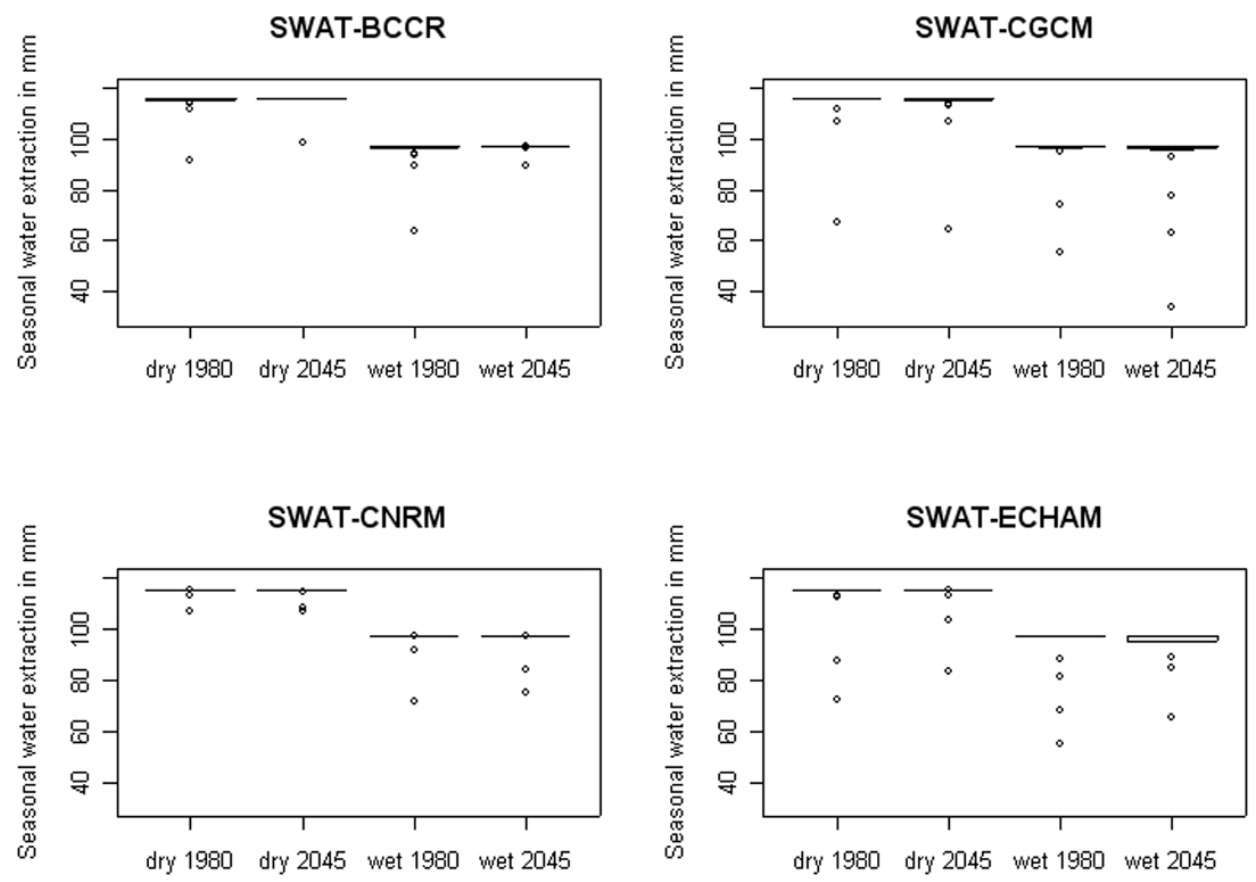

Figure 6 Seasonal distribution of simulated dry and wet season water extraction for the four SWAT-GCMs. The median and quartiles shown in these box-plots are close together and match the water demand. The circles represent outliers. 


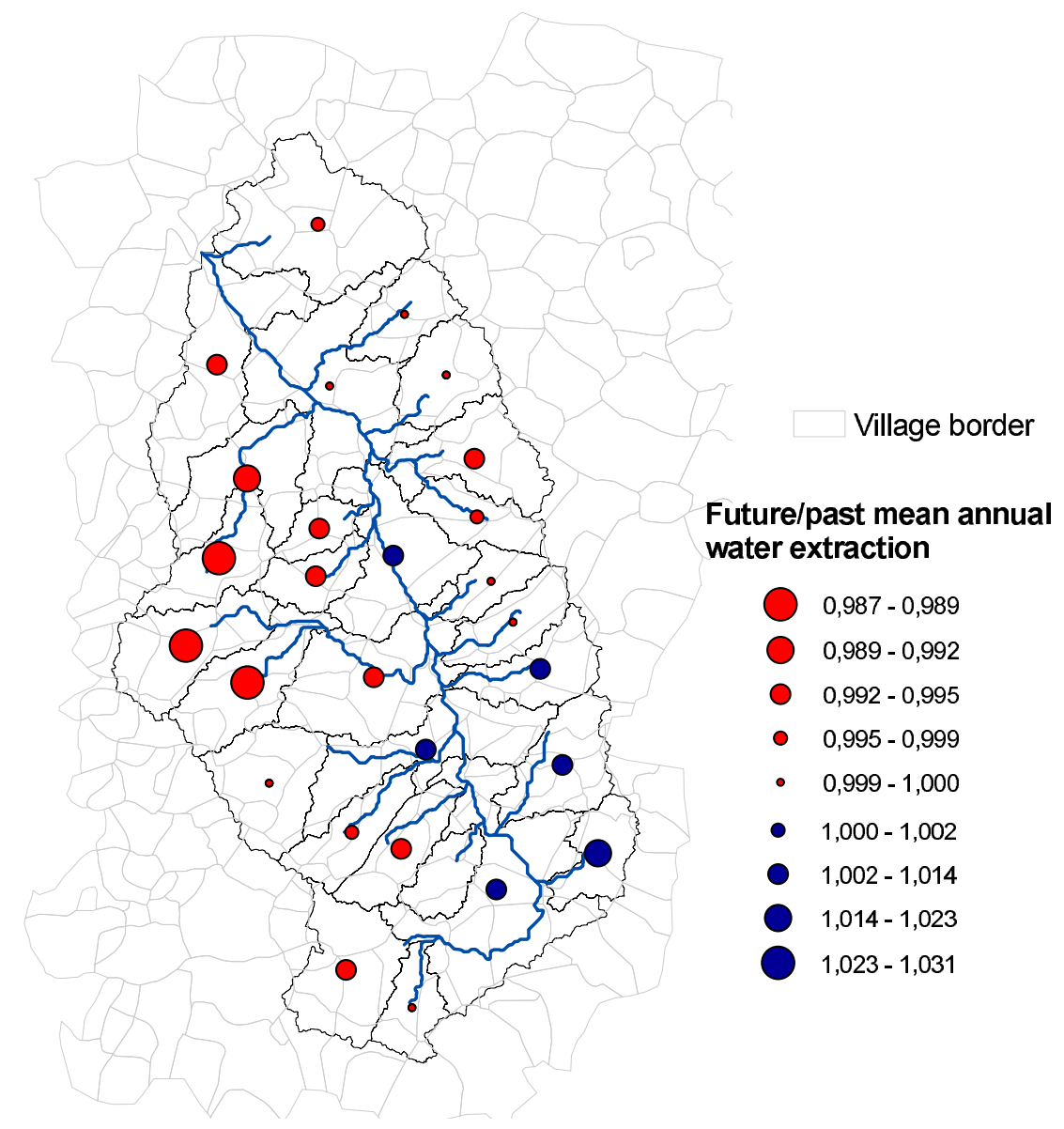

Figure $7 \mid$ Projected future/historical water extraction ratio per sub-basin for the multi-model SWAT-GCM scenario. The red and blue circles represent a decrease and an increase in water extraction respectively, under present agricultural practices. The size of the symbol is proportional to the intensity of the climate change impact. Made with ESRI 2009. ArcMap Version 9.3.1.

up-scaling from local calibration (Gajwel area) to basin-wide application (Kudaliar catchment area), because of a paucity of time series of hydrological data.

The multi-model SWAT-GCM considers each climate scenario to be equally likely. The average GWS increase by $50 \mathrm{~mm}$ estimated under this scenario corresponds to an increase about $30 \%$ of the groundwater recharge under CC. This is comparable to previous estimates made by global simulations that projected increases in potential recharge of more than $30 \%$ in the Sahel, Middle East, northern China, Siberia, and the western United States, and decreases in potential groundwater recharge of more than $70 \%$ by the 2050s (northeast Brazil, southwest Africa, and along the southern rim of the Mediterranean Sea $)^{44}$.

An increase in river discharge is also projected during the monsoon season, whose first discharge events occur earlier in June. No noticeable increase in runoff caught in the WHS is projected, as its capacity was already fully used during wet years in the past.

This study is an illustration of how shallow aquifers subjected to high IWD react to climate variability. Fisherman et al..$^{45}$ demonstrated that over-extraction of groundwater could lead to long term declines of water table in deep alluvial aquifer (Punjab area in India) while shallow low storage aquifer (in Andhra Pradesh area) cannot naturally experience long term decline in water table. In this second context, in what sense are the extractions excessive? The agricultural water management should adapt to the short-term reliability of water supply rather than long-term sustainability. Pavelic et al. ${ }^{46}$, describe the buffer effect of the shallow aquifer in cases of climatic drought for the irrigation supply in Maharashtra (a semi-arid area with shallow basaltic aquifers) in relation to the overall decline in well productivity associated with the drop in water level ${ }^{46}$. They estimated that two or more years of climatic drought lead to hydro-geological drought, affecting farming activities. Shortages affect the entire community, since it is a food-producing system. Governmental statistics report an increase in the extent of irrigated areas of $28 \%$ during the 1980 s and by another 105\% during the 1990s, in Andhra Pradesh. In the nowadays situation described in figure 2 , farmers cannot count on the aquifer buffer effect, because the water table is alarmingly low. Restricting the extent of the irrigated area is already the main coping measure employed by farmers when facing drops in borehole productivity.

Coping measures implemented by the government to limit GWE, such as better irrigation practices (drip irrigation in vulnerable areas) and less water-intensive crops, should be supplemented by a continuous and spatially representative groundwater storage monitoring system designed to manage the buffer effect of the aquifer, which could provide emergency irrigation water in the event of successive severe climatic droughts. These coping measures and controls should mitigate the food security hazard this region is facing.

The present study is an illustration of potential projected changes in areas with low storage crystalline aquifers under tropical semi-arid conditions. In these regions, due to shortage of surface water, groundwater-fed irrigation is developing (i.e. South-East Asia) or is expected to develop (i.e. Africa) with an increasing competition between water availability and water demand ${ }^{16}$. The implementation of a spatial agro-hydrological model to dynamically investigate this spatial competition under climate variability at the watershed scale reveals the importance of accounting for local situations. 
2009 and March 2010, in which each growing crop was identified at the plot scale in 25 sampled areas, later used for classification. The irrigated area comprises small plots (rice paddies or vegetable plots) scattered around the landscape, irrigated either from boreholes during two growing seasons or over one season. For a given irrigated crop, daily pumping rate estimates were obtained from farmers. For rice, vegetables, and fruit trees, a linear relationship exists between the pumping rates and the extent of the irrigated area under each crop ${ }^{28,56}$. The land-use map also enabled estimation of the maximum surface area and volume of the WHS set up and maintained by farmers to retain runoff and to help recharge the aquifer.

Evaporation from the water table was ignored as it is generally more than seven $\mathrm{m}$ below the surface. The main simulated inflows for the aquifer are the spatial recharge, (percolation of the portion of rain not used by plant evapotranspiration), the "return flow" (the infiltrated, unconsumed portion of the irrigation water for flooding rice paddies), and to a smaller extent the recharge from stream water percolating through the stream bed. Farmers use a large volume of water to flood rice paddies with 9 to $12 \mathrm{~mm} /$ day of irrigated water (more than $2000 \mathrm{~mm} /$ year) during the monsoon and dry season respectively. Half of this volume is estimated to flow back into the aquifer, while the other half evaporates (some as plant transpiration and the remainder as surface water and soil evaporation $)^{21,57}$. The regional horizontal flow was ignored as it has been estimated to be less than $5 \mathrm{~mm} \cdot \mathrm{y}^{-1}$ in the same agro-climato-hydrogeological context ${ }^{22}$

SWAT simulations for the future period (2045-2065), were performed assuming a static land-use map, meaning that changes in the simulated hydrological variables are driven only by future climate developments. the spatial distribution of evapotranspiration ${ }^{50}$. Although mainly used for large catchment areas, it has been validated for small ones, e.g., for hydrology, as in Green and Van Griensven ${ }^{51}$, for nitrate flows in stream simulation ${ }^{51}$, and for groundwater in a semi-arid area in southern India ${ }^{25}$. It has also been considered relevant for assessing the impact of CC on the water cycle and the fate of nutrients ${ }^{52}$.

The spatial resolution for the SWAT model is the sub-catchment area (sub-basin), further divided into hydrologic response units (HRUs). Each HRU is delimited according to the overlying soils and land-use and gradient maps. Vertical water flows are simulated at the HRU scale: the actual evapotranspiration and recharge estimates are mainly based on the soil crop model (Erosion Probability Impact Calculator EPIC $)^{53}$. Sowing, harvesting or tillage, and daily irrigation and fertilization can be carried out on an HRU scale. Each horizontal water flow reaches the stream directly, irrespective of the position of the HRU in the sub-basin. Transmission through the stream bed and the storage of water in a reservoir are simulated on a sub-basin scale. A shallow aquifer is conceptualized as an independent reservoir for each sub-basin (whose limits are defined by the user on the basis of the Digital Elevation Model analysis). Groundwater discharges into the stream when the groundwater level reaches a particular threshold. This threshold has been estimated for each sub-basin using aquifer capacity maps (see below). Several studies have been performed, coupling SWAT with a groundwater flow model (MODFLOW), to formally investigate groundwater flow dynamics ${ }^{54,55}$. In the context of our study area, the groundwater level remains in the fissured layer and there is no permanent river flow (meaning that the groundwater and surface flows are weakly connected). Moreover, lateral regional groundwater flow at the basin limits has been found by Maréchal et al. ${ }^{22}$ to be negligible compared to vertical flows (a complete discussion is provided by Perrin et al. ${ }^{25}$ ). Consequently, the simple reservoir-modeling approach used in the SWAT model to simulate groundwater storage at sub-basin scale is assumed to be appropriate for our study's objectives.

SWAT was calibrated/validated for a small catchment area, the town of Gajwel, a catchment covering $84 \mathrm{~km}^{2}$ and embedded in the Kudaliar catchment area ${ }^{25}$. The Gajwel catchment is representative of the Kudaliar catchment in terms of aquifer structure, water-table depth, and agricultural activities. Perrin et al. ${ }^{25}$ calibrated the seasonal recharge and return flow from 2006 to 2010 using seasonal estimates derived from piezometric observations. The validation procedure was carried out on monthly groundwater-storage estimates over the period from 2000 to 2010 . For this validation period, the annual variation in the extent of the irrigated area was calculated using government statistics.

For the modeling performed in this study, the pool of parameters calibrated on the recharge and return flow for the Gajwel catchment was applied at the scale of the Kudaliar catchment. The relationship between tank surface and tank volume capacity, calculated by Perrin et al. ${ }^{25}$ for tanks monitored in the Gajwel catchment, was used to define the surface reservoir geometry in each sub-basin of the Kudaliar catchment. The average maximum groundwater reservoir storage capacity was estimated by combining the porosity maps compiled by Dewandel et al..$^{24}$ and maps of bedrock depth and saprolite/fissured granite layer contact-zone depth constructed from field observations. The actual percolation reservoir capacity of the WHS was aggregated into a single notional reservoir for each sub-basin.

Evapotranspiration is simulated by SWAT on the basis of the crop characteristics and growth simulated from the soil-crop module. Groundwater extraction by pumping is mainly used for flooding rice paddies on a daily basis or for other irrigation methods (vegetables irrigated every three days or, less frequently, drip irrigation). It was computed on a daily basis using the irrigation demand and the simulated groundwater availability. The spatial distribution of the irrigation demand over the catchment was estimated at the plot scale, based on the type of crop and on the observed irrigation practices. Types of crops are obtained from the land-use maps shown in Figure 1b, which have been integrated into the SWAT model. To obtain this map, a supervised classification was performed on LISS- 4 images for the 2009 Kharif season and the following 2010 Rabi season, with training and validating ground data. The ground data were acquired during two land-cover surveys carried out in October

1. Pachauri, R. K. \& Reisinger, A. Climate Change 2007: Synthesis Report. Contribution of Working Groups I, II and III to the Fourth Assessment Report of the Intergovernmental Panel on Climate Change. (Core Writing Team, Pachauri, R. K. \& Reisinger, A. Geneva, 2007).

2. Ardoin-Bardin, S. et al. Using general circulation model outputs to assess impacts of climate change on runoff for large hydrological catchments in West Africa. Hydrolog. Sci. J. 54, 77-89 (2009).

3. Caballero, Y. et al. Hydrological sensitivity of the Adour-Garonne river basin to climate change. Water Resour. Res. 43, W07448 (2007).

4. Fowler, H. J., Kilsby, C. G. \& Stunell, J. Modelling the impacts of projected future climate change on water resources in northwest England. Hydrol. Earth. Syst. Sc. 11, 1115-1126 (2007)

5. Minville, M. et al. Adaptation to climate change in the management of a canadian water-resources system exploited for hydropower. Water Resour. Manage. $\mathbf{2 3}$ 2965-2986 (2009).

6. Taylor, R. G. et al. Groundwater and climate change. Nature Clim. Change, 3, 322-329 (2013).

7. Goderniaux, P. et al. Large-scale surface-subsurface hydrological model to assess climate change impacts on groundwater reserves. J. Hydrol. 373, 122-138 (2009).

8. Holman, I. P., Tascone, D. \& Hess, T. M. A comparison of stochastic and deterministic downscaling methods for modelling potential groundwater recharge under climate change in East Anglia, UK: implication for groundwater resource management. Hydrogeol. J. 17, 1629-1641 (2009).

9. Scibeck, J. \& Allen, D. M. Modeled impacts of predicted climate change on recharge and groundwater levels. Water Resour. Res 42, W11405 (2006).

10. Jyrkama, M. I. \& Sykes, J. F. The impact of climate change on spatially varying groundwater recharge in the Grand River watershed (Ontario). J. Hydrol. 338, 237-250 (2007)

11. Döll, P. Vulnerability to the impact of climate change on renewable groundwater resources: a global-scale assessment. Environ. Res. Lett. 4, 035006 (2009).

12. Gurdak, J. J. \& Roe, C. D. Review: recharge rates and chemistry beneath playas of the High Plains aquifer, USA. Hydrogeol. J. 18, 1747-1772 (2010).

13. Kovalevskii, V. S. Effect of climate changes on groundwater. Water resour. $\mathbf{3 4}$, 140-152 (2007)

14. Green, T. R. et al. Physically based simulation of potential effects of carbon dioxide-altered climates on groundwater recharge. Vadose Zone J. 6, 597-609 (2007).

15. Döll, P. et al. Impacts of water withdrawals from groundwater and surface water on continental water storage variations. J. Geodyn. 59-60, 143-156 (2012).

16. Wada, Y., Van Beek, L. P. H. \& Bierkens, M. F. P. Nonsustainable groundwater sustaining irrigation: A global assessment. Water Ressour. Res., 48, W00L06 (2012).

17. Biswas, A. K., Rangachari, R. \& Tortajada, C. Water Resources Of The Indian Subcontinent. Oxford University Press, USA, Chapter 2 (2009).

18. Tiwari, V. M. et al. Land water storage variation over Southern India from space gravimetry. Curr. Sci. 101, 536-540 (2011).

19. Reddy, D. V. et al. Understanding hydrological processes in a highly stressed granitic aquifer in southern India. Hydrol. Process. 23, 1282-1294 (2009).

20. Dewandel, B. et al. A generalized 3-D geological and hydro-geological conceptual model of granite aquifers controlled by single or multiphase weathering. J. Hydrol. 330, 260-284 (2006).

21. Dewandel, B. et al. A decision support tool with variable agro-climatic scenarios for sustainable groundwater management in semi-arid hard rock areas. Curr. Sci. 92, 1093-1102 (2007) 
22. Maréchal, J. C. et al. Combined estimation of specific yield and natural recharge in semi-arid groundwater basin with irrigated agriculture. J. Hydrol. 329, 281-293 (2006).

23. Maréchal, J. C., Dewandel, B. \& Subrahmanyam, K. Use of hydraulic tests at different scales to characterize fracture network properties in the weatheredfractured layer of a hard rock aquifer. Water Resour. Res. 40, W11508 (2004).

24. Dewandel, B. et al. Upscaling and regionalizing hydraulic conductivity and effective porosity at watershed scale in deeply weathered crystalline aquifers. J. Hydrol. 416-417, 83-97 (2012).

25. Perrin, J. et al. Assessing water availability in a semi-arid watershed of southern India using a semi-distributed model. J. Hydrol. 460-461, 143-155 (2012).

26. Arnold, J. G. et al. Large-area hydrologic modeling and assessment: Part I. Model development. J. American Water Resources Association 34, 73-89 (1998).

27. Rajeevan, M. \& Bhate, J. A high resolution gridded rainfall dataset (1971-2005) for mesoscale meteorological studies. Curr. Sci. 96, 558-562 (2009).

28. Massuel, S. et al. A simple low-cost method to monitor duration of ground water pumping. Ground Water 47, 141-145 (2008).

29. Green, T. R. et al. Beneath the surface of global change: Impacts of climate change on groundwater. J. Hydrol. 405, 532-560 (2011).

30. Flato, G. M. et al. The Canadian Centre for Climate Modeling and Analysis of Global Coupled Model and its climate. Climate Dynam. 16, 451-467 (2000).

31. Salas-Melia, D. et al. Description and validation of the CNRM-CM3 global coupled model. CNRM working note 103, (2005).

32. Jungclaus, J. H. et al. Ocean circulation and tropical variability in the coupled model ECHAM5/MPIOM. J. Clim. 19, 3952-3972 (2006).

33. Furevik, T. et al. Description and evaluation of the Bergen Climate Model: ARPEGE coupled with MICOM. Climate Dynam. 21, 27-51 (2003).

34. Nakicenovic, N. et al. Special Report on Emissions Scenarios: a special report of Working Group III of the Intergovernmental Panel on Climate Change. (Nakicenovic, N. \& Swart, R. Cambridge, 2000).

35. Kripalani, R. H. et al. South Asian summer monsoon precipitation variability: Coupled climate model simulations and projections under IPCC AR4. Theor. Appl. Climatol. 90, 133-159 (2007).

36. Vigaud, N., Vrac, M. \& Caballero, Y. Probabilistic downscaling of GCMs scenarios over southern India. Int. J. Climatol. 33, 1248-1263 (2012).

37. Taylor, R. G. et al. Evidence of the dependence of groundwater resources on extreme rainfall in East Africa. Nature Clim. Change 3, 374-378 (2013).

38. Owor, M. et al. Rainfall intensity and groundwater recharge: evidence from the Upper Nile Basin. Environ. Res. Lett. 4, 035009 (2009).

39. Landerer, F. W. \& Swenson, S. C. Accuracy of scaled GRACE terrestrial water storage estimates. Water Resour. Res. 48, WR011453 (2012).

40. Swenson, S. \& Wahr, J. M. Post-processing removal of correlated errors in GRACE data. Geophys. Res. Lett. 33, L08402 (2006).

41. Simonneaux, V. et al. The use of high-resolution image time series for crop classification and evapotranspiration estimate over an irrigated area in central Morocco. Int. J. Remote Sens. 29, 95-116 (2008).

42. DelSole, T. \& Shulkla, J. Climate models produce skillful predictions of indian summer monsoon rainfall. Geophys. Res. Lett. 39, GL051279 (2012).

43. Bates, B. C. et al. Climate Change and Water, IPCC Technical Paper VI, IPCC Secretariat, Geneva (2008).

44. Döll, P. \& Fiedler, K. Global-scale modeling of groundwater recharge. Hydrol. Earth. Syst. Sc. 12, 863-885 (2008)

45. Fisherman, R. M. et al. Over-extraction from shallow bedrock versus deep alluvial aquifers: Reliability versus sustainability considerations for India's groundwater irrigation. Water Resour. Res. 47, W00L05 (2011).

46. Pavelic, P. et al. Role of groundwater in buffering irrigation production against climate change variability at the basin scale in South-West India. Agr. Water Manage. 103, 78-87 (2012).

47. Arnold, J. G. \& Allen, P. M. Estimating hydrologic budgets for free Illinois watersheds. J. Hydrol. 176, 57-77 (1996).
48. Santhi, C. et al. A modelling approach to evaluate the impacts of water quality management plans implemented in a watershed in Texas. Environ. Modell. Softw. 21, 1141-1157 (2006)

49. Faramarzi, M. et al. Modeling wheat yield and crop water productivity in Iran: Implications of agricultural water management for wheat production. Agr. Water Manage. 97, 1861-1875 (2010).

50. Immerzeel, W. W. \& Droogers, P. Calibration of a distributed hydrological model based on satellite evapotranspiration. J. Hydrol. 349, 411-424 (2008).

51. Green, C. H. \& Van Griensven, A. Aurocalibration in hydrologic modeling: Using SWAT2005 in small-scale watersheds. Environ. Modell. Softw. 23, 422-434 (2008).

52. Ferrant, S. et al. Understanding nitrogen transfer dynamics in a small agricultural catchment: comparison of a distributed (TNT2) and a semi distributed (SWAT) modelling approaches. J. Hydrol. 406, 1-15 (2011).

53. Williams, J. R., Jones, C. A. \& Dyke, P. T. A modelling approach to determining the relationship between erosion and soil productivity. Trans. ASAE 27, 129-144 (1984).

54. Kim, N. W. et al. Development and application of the integrated SWATMODFLOW model. J. Hydrol. 356, 1-16 (2008).

55. Sophocleous, M. A. et al. Integrated numerical modeling for basin-wide water management: The case of the Rattlesnake Creek basin in south-central Kansas. J. Hydrol. 214, 179-196 (1999).

56. De Condappa, D. et al. Bimodal Zone of the Soil Textural Triangle: Common in Tropical and Subtropical Regions. Soil Sci. Soc. Am. J. 72, 33-40 (2008).

57. Maréchal, J. C. et al. Anisotropie verticale de la perméabilité de l'horizon fissuré des aquifères de socle: concordance avec la structure géologique des profils d'altération. C. R. Geosci. 335, 451-460 (2003).

\section{Acknowledgments}

This study was supported by the National Research Agency (Agence Nationale pour la Recherche - ANR) through the VMCS program (SHIVA project, Contract ANR 08 VULN 010 01, www.shiva-anr.org) and the French Geological Survey (Bureau de Recherches Géologiques et Minières - BRGM). The authors would like to thank their SHIVA partners for their contribution. Documentation concerning the ANR SHIVA project methodology is available at http://www.shiva-anr.org/publishedpapers.html. GRACE land data were processed by Sean Swenson, supported by the NASA MEaSUREs Program, and are available at http://grace.jpl.nasa.gov.

\section{Author contributions}

S.F. implemented and validated the SWAT model using the available data; S.F. and Y.C. performed the statistical analysis of the simulations. F.D., J.P. and S.F. carried out the land-cover survey; S.A. collected relevant historical agricultural practice data. F.D. classified the satellite data for land cover for each season. J.C.M. and B.D. designed the geological monitoring and performed the aquifer-capacity mapping. S.G. and S.F. performed the SWAT validation using GRACE data. J.C.M. and Sh.A. have worked on the project since its inception. S.F. prepared the figures and wrote the manuscript with input from all team members.

\section{Additional information}

Competing financial interests: The authors declare no competing financial interests.

How to cite this article: Ferrant, S. et al. Projected impacts of climate change on farmers' extraction of groundwater from crystalline aquifers in South India. Sci. Rep. 4, 3697; DOI:10.1038/srep03697 (2014).

This work is licensed under a Creative Commons AttributionNonCommercial-NoDerivs 3.0 Unported license. To view a copy of this license, visit http://creativecommons.org/licenses/by-nc-nd/3.0 